\title{
Influence of Family Background on Social Adjustment of Adolescent Students of Southern Senatorial District of Cross River State, Nigeria
}

\author{
Paulina Akpan-Idiok ${ }^{1 *}$, Aniebietabasi Ackley ${ }^{2}$ \\ ${ }^{1}$ Department of Nursing Sciences, Faculty of Allied Medical Sciences, University of Calabar, Calabar, Nigeria \\ ${ }^{2}$ School of Architecture, Faculty of Architecture and Design, Victoria University of Wellington, New Zealand \\ *Corresponding Author: Paulina Akpan-Idiok, Department of Nursing Sciences, Faculty of Allied \\ Medical Sciences, University of Calabar, Calabar, Nigeria
}

\begin{abstract}
Studies have reported the rising spate of antisocial activities among secondary school students. But, there are questions about why, and what are the root causes of these antisocial activities among student, which is yet to be answered? Among the youths, family background provides the basic foundation and the most valuable and indispensable school of socialization. In a typical African family setting, the family is the most basic unit of life which represents the miniature life of the entire people in a community. The aim of this study was to determine the influence of family background on adolescent social adjustment in Southern senatorial district of Cross River State, Nigeria. Four research hypotheses were formulated for this study and tested at .05 level of significance with 348 degrees of freedom. A well validated 23-item questionnaire was used to collect the required data. The data collected was tested using the independent t-test analysis for the hypotheses. From the analysis, the following findings were made among others: there is a significant influence of family type on student's social development $(P>0.05)$. Family structure significantly influence student's social adjustment. The study will be of great benefit to the parents, students, teachers, educational planners, policy makers, counselors, psychologists, religious bodies and future researchers. This is so because the findings reveals the actual causes of and remedy to antisocial behaviour among students. The parents would be informed of the role of family background in the socialization of adolescents.
\end{abstract}

Keywords: influence family background, adolescents and social adjustment

\section{INTRODUCTION}

Social adjustment and economic activities also centers around the family background in which each individual has his own part to play. The family as a social institution is governed by social norms. The family is a primary unit in every society (Njama-Abang 2006). Procreation and mating behaviour of individuals are regulated mainly through the family institution. The family background is also responsible for the care, protection, socialization and education of the child (Denga, 2006). Later education is by the society and the school.

The family is not just meant for procreation but it enhances the learning of values, attitude, knowledge, skills and techniques of a given culture (Wattesubeag, 1973, Eyo, 2002 and Christian, 2005). Christian (2005) opines that in the family, individuals are closely bound to each other, both because of blood or marriage, and because of living together. By this, individuals in the family exert some positive negative influence on each other. Similarly, Kalu (2005) suggested that it may not be an over statement to say that family background influences individual social adjustment. This is to say that the family background where the adolescent student has dual effect or influence on the social development.

The National Policy of Education (1981) according to Denga (2004:15) asserted that at all levels of instructions must be oriented towards inculcating the following values:

'Respect for worth and dignity of the individual; faith in man's ability to make rational decisions; moral and spiritual principle in interpersonal and human relations, share responsibility for the common good of society, promote the physical, emotional and psychological development of all children, and acquisition of competencies necessary for self reliance'. 
This is aimed at building a peaceful and socially adjusted society. Our nation today, is being invaded with many antisocial and unsocial activities especially on the very issues that are keen to the foundation of life, socialization and co-existence. Despite the efforts made in 1977 by the then Head of State and Commander in Chief of the Armed Forces-Lt. General Olusegun Obasanjo on this social malady, and General Buhari and General Idiagbon who in 1984 instituted War Against Indiscipline Campaign in a bid to restore moral rectitude and modest living in the populace, the media reports that not one day passed without news of arm robbery, arson, promiscuity, violent demonstration, delinquencies, examination malpractices, and students unrest even militant activities which even disvirgined many Nigerian virgins (Nations News Paper Dec. 23/09:5, Denga, 1991, Attoe, 1999).

Thousands of crimes and indiscipline cases are being credited mostly to our youth and adolescent children (Imaobong, 2002). Many psychologists upheld to social adjustment as the ability to adapt oneself to social activities, ability to cope with laid down standards of behaviour, ability to master challenges to interact with one's environment and develop good conscience, deal appropriately with anxiety and conflict (Kalu, 2008; Delvega and Juada, 1998; Ozoemena, 2002).

In a study by Kalu (2008), it was reported that antisocial activities are prominent within the secondary school age (11-18 years). These calibers of maladjusted students do find it difficult to get along with fellow students and their family members, friends, peers, school teachers, some could get engaged in self destruction and even that of others they manifest aggressive tendencies, aggression, deviancy and drug abuse. Some secondary school students have come to regard pre-marital sexual activities as the private personal affairs of the participants and no business of anyone else (Akpan 1975; Kalu 2008). The school and government have tried several disciplinary efforts to stop these antisocial activities among students but to no avail (Kalu, 2008 and Eyo, 2002).

The questions to answer are why and what are the root causes of these antisocial activities among student? Hence the concern for this research study. Njama-Abang (2006) opined that family background is the basic foundation and the most valuable and indispensable school of socialization among the youths. And Kalu (2008) posited that the concept of the family 'covers' a wide range of members thus: children, parents, grandparents, aunts, and other relatives. The family then is the most basic unit of life which represents the miniature life of the entire people.

Social learning theorists, the likes of skinner (1953) and Bandura (1977) seem to address the problems of antisocial behaviours. In their own observations, they speculated that "there is no behaviour without the root cause". In continuous search for solution to antisocial behaviour among students, the social learning theorists-Skinner (1953), Bandura (1977) observed that there is no behaviour without the root cause. On the basis of the foregoing, this study seeks to find out what and how family background variables such as type and structure of family, family size and parenting styles relates or influence social adjustment of secondary school student. The family gives a sense of belonging by showing love to an individual and is the first agent of the child's socialization. One of the major functions of the parents and others within the family set up is preparing the child for life outside the larger society.

\section{Theoretical Background}

The following theories are considered in this study to form the body of knowledge that guide and proffer the foundation for this research. They are:

1. Theories of adolescence

2. The psychodynamic theories of family

3. The social learning theory

\section{Theories of Adolescence}

This will be reviewed under psychosocial theory and psychoanalytical theory.

\section{Psychosocial Theory of Adolescence}

Erickson (1954) posited that there is a search for a sense of self or self identity during adolescence as the youth asks "who am I", 'what am I to do?' on a quest about the role of the family and society in 
the life of the adolescent, he observed that the adolescents relationship with his parents at this time essentially physical and marginally social.

Kalu (2008), Onyeyiaku (1991) thus appraised that the probability of successful accomplishment of the demands of adolescents is dependent on the person's history of ego achievement and failures. Also, the ego achievement and failure of the adolescent is determined by the home and the larger society. Hence, the tendency to over identify with heroes or cliques with the possibility of fixation on a negative identity which is a devoted attempt to become what parents and community do not want him to be.

The above theory accounts for moral development in terms of child's reinforcement history. Adolescent's social adjustment is the acquisition of cultural values, the conditioning moral anxiety is conscience, and moral characters are learnt habits. That which is good is that which is enforced. Social norms are inculcated by parents and teacher, or by secondary reinforcement of association with them, and by initiation of models whom the adolescent can identify within his home environment.

\section{Psychoanalytic Theory of Adolescents}

Freud (1933) asserts that adolescent's behaviour is a product of early socialization process and childhood experiences, which implies that, the adolescent's behaviour is rooted in what has happened to him during his earlier childhood development. According to Freud, the personality (mind) is made up of the Id, ego and superego. The Id is the raw, blind, primitive core of the unconscious, ignorant of good and evil which seeks to gratify the sex and aggression drives (source of psychic-energy), the ego is the rely which uses some of the defense mechanism to yield outlet to Id impulses or represses the anxiety while the ego is comparable to conscience or character (Njama-Abang 2006).

This theory implies that an adolescent's behaviour should be viewed in relation to his family background, the family type and structure or models that exert indelible impact on the personality of the adolescent. The parenting style will account for their adjustment and for normal personality development. No mortal could be greater than his environment. The parents and other must play a role model "instructional material" in order for adolescent to learn and adjust radically for the good of the society.

\section{The Psychodynamic Theory of Family}

The anthropologists have seen the significant influence of the family on the social behaviour of man Kalu (2008), Eyo (2002). There is variation of human behaviour from one home to the other, adding that violation occur, for the most part, through transmission to another 'self' is derived from interaction with his social world, which in its narrow sense, refers to his family (Mead, 1934). A child from a fractional family will be rebellious against family standards; he will carry this habit into his social relationships outside the family or into the school.

Implications of the theory: the family climate exerts impact on the adolescents positively or negatively, depending on the family background or the community an adolescent is grown. Moreover, variation in the level of social adjustment of the adolescents, is dependent on the individual family differences or variation in family's climate.

The parents should create socially adjusted family and society as a catalyst for production of socially adjusted adolescents.

\section{The Social Learning Theory}

Bandura (1971) theorized that a large part of what a person learns occur through imitation or modeling. That behaviours are modified during social interactions. Models are classified into two groups - real life model and reinforcement model.

Deductively, parents remain the primary instructional materials for the children and adolescents. The parents and society should not expect their offspring to exhibit a high level of morality or social adjustment on isolation. In the book of (Genesis 1:24) the natural law has it that every tree, seed or person must produce his kind. Adolescents reinforces their models. This is so in that positive reinforcement based on this theory strengthens responses and development and tendency for the response to repeat itself in future. The family type, structure, size and other family background variables may contribute in shaping the characters of the adolescents. 


\section{Statement of the Problem}

It is disheartening to note that antisocial activities/bahaviours are still perpetuated by our sons and daughters in this $21^{\text {st }}$ century. According to Nigerian media report that not a day passes without news of armed robbery, arson, promiscuity, violent demonstration, delinquency, examination malpractices, and students unrest (Attoe, 1999; Imaobong, 2002). These endemic epidemics call for urgent arrest to save our states and nation from imminent decay. Despite the efforts made by the government of Nigeria three decades ago, to restore moral rectitude and modest living in our society, the exercise proved abortive (Kalu, 2008 \&Imaobong, 2002).

In an area which families, schools and indeed the general society are plagued and torn apart by various forms of antisocial activities, the concern of parents, teachers, students and government has been on identifying the toot cause of the problem and the appropriate measures to deal with them/it. The major focus of this study is therefore on addressing the influences the family background hason the social adjustment of adolescent students.

\section{Purpose of the Study}

This aims at determining the influence of family background on social adjustment of adolescent's students in Southern Senatorial District of Cross River State.

The specific objectives are to:

1. Determine the influence of family type on student's social adjustment of adolescent

2. Determine if family structure influences social adjustment of adolescent students.

3. Determine if family size influence social adjustment of adolescent students

4. Determine how family/parental attitude influences social adjustment of adolescent students.

\section{Research Questions}

1. How does family type influence student's social adjustment?

2. What influence has family structure on student's social adjustment

3. How does family size influence student's social adjustment?

4. How does family parental attitude influences student's social adjustment?

\section{Research Hypotheses}

This deals with the following three null hypotheses:

1. There is no significant relationship between adolescent student's family type and social adjustment.

2. There is no significant relationship between adolescent student's family structure and social adjustment

3. There is no significant relationship between adolescent student's family size and social adjustment.

\section{Assumption of the Study}

The study is based on the following two assumptions:

1. Family in southern senator district of cross river state differ in types, structure and size.

2. Parents families have attitudes which are unique to them and their adolescent children.

\section{Significance of the study}

The study will be of great benefit to the parents, students, teachers, educational planner, policy makers, counselors, psychologists, religious bodies and future researchers. This is so because the findings may reveal the actual causes of and remedy to antisocial behaviour among students. The parents would be informed of the role of family background in the socialization of adolescents.

Teachers would equally find the results of this research very relevant as it would proffer strategies with which to assist the students in proper social development. 
The findings of this study would also assist the counselors and psychologists in evolving more effective therapeutic intervention strategies to facilitate social development and curb antisocial behaviour among adolescents.

The results of this study would also enable the religious bodies to realize the need to intensify efforts in the propagation and re-orientation of societal values that are critical to social adjustment.

Future researchers would find the data obtained from this investigation very useful especially when further studies are required.

It will also help the educational planners, policy makers to include such instructional materials that are meaningful and relevant to our national educational goals (both for private and public schools) to inject sanity into our society and our nation will be lifted from its present immoral antisocial situation to a free and democratic society, just and egalitarian society, great and dynamic economy, a land full of bright opportunities for all citizens (National Policy on Education, 1981). The future parents would come to lamb light that an adjusted family is the product of an adjusted society. Finally, this study will encourage further research.

\section{Scope of the Study}

The study covered only secondary school students' family background, the family structure, the family size and parental attitude on the social adjustment of students. The study was limited to only students from JSS 1-3. It is assumed that at the early adolescence, they have started secondary school and that the child can group and deal with the demands of the instrument on family backgrounds and social adjustment. The study covered only the Southern Senatorial District of Cross River State (Akamkpa, Akpabuyo, Bakassi, Biase, Calabar Municipality, Calabar South and Odukpani Local Government Areas).

\section{LITERATURE REVIEW}

This chapter reviewed the relevant literature on family background and social adjustment of secondary school adolescent students. The purpose of this review is to provide a background that would be appropriate for understanding what is currently known about the study. The theoretical and empirical information considered the influences of family type and family structure on social adjustment of adolescent students. The influence of parental attitude on the social adjustment of adolescent students was also discussed:

- Influence of family type on the social adjustment of adolescent students.

- Influence of family structure on the social adjustment of adolescent students.

- Influence of family size on the social adjustment of adolescent students

- Influence of parental attitude on the social adjustment of adolescent students.

\section{Influence of family type on the social adjustment of adolescent students.}

The family is one of the institution essential for the survival of any society. The family as a primary unit in every society os a divine educational institution charged with the responsibility of socialization and spiritualizing the group ones into potential adult (Njama-Abang, 2006; Christian, 2005; Leshe, 1979). Eyo (2002) described the family as a social institution governed by social norms. These norms functions for the survival of family members and the society. The family enables not only the process of procreation but enhances the learning of values, attitude, skill and techniques of a given culture (Kalu, 2008; Njama-Abang, 2006).

Bell and Vogel (1986) in their study of families in U.S.A. found that, that family as an arena of interacting personalities plays the central role in personality build up and socialization process of an individual. Early personality formation starts with the family. According to Taff and England (1980), Eyo (2002) and Kalu (2008) the family is the first training school in both behaviour and misbehavior. If the attitude of both parents are in harmony with each other, and with the accepted codes of conduct of the general community the home can effectively transmit cultural and moral values to oncoming generation. 
In another study on the effect of family atmosphere and values on adolescents' moral development. The sample consisted of 168 respondents. The results showed that $84 \%$ of the respondents agree with the following statement.

1. Family leads to moral or immorality among adolescent

2. Parents not establishing moral standard for their children lead to unhealthy character development.

3. Parents misplaced values lead children to confusion about priorities (Mmaduakonam, 198:132)

Confirmatorily from this research, the family is the adolescents model. The social learning theory gives a comprehensive view of parental role in socializing children. Through imitation and modeling, children are able to imbibe the standards and value system of the patents (Imaobong, 2002). A study on juvenile delinquency by Onyehalu in the year 1986 revealed that family background is directly related to juvenile delinquency. It was very remarkable that if parents do not appear living, caring and sympathetic, the child will always develop a negative perception of himself which may pre-dispose the child to disciplinary problems.

Okon (1994) confirmed the above assertion in a study of adolescents antisocial behaviour. Three hundred and sixty (360) boys and three hundred and Sixty (360) girls were used for the study which revealed that adolescents who were reared in families where there is lack of warmth may likely expose the adolescent to antisocial behaviour such as truancy, alcoholism and drug use. Juvenile delinquency, unsocial behaviour and other antisocial vices are blamed on family that lack unity and friendly atmosphere. Christian (2005) in Kalu (2008) studies supported that adolescent antisocial activities stems from family background. By implication, conditions existing in the family go a long way to either enhance or militate against the adolescents' socialization process which inculacation of moral value is a part. (Zimmermann, 1973, Power, 1988; Eyo, 2002 \& Kalu, 2009).

According to Kalu (2008) in Nigeria, there are many family types discernible in forms of monogamous and polygamous families, and many family structures are in form of intact and broken family.

\section{RESEARCH METHODOLOGY}

The methodology and design applied for this study is represented under the following sub-headings:

Research design, research area, the population of the study, the sample, the sampling techniques, the instrumentation, validation of instrument, reliability of instrument, the procedure for data collection, data preparation and coding and the method of data analysis.

\section{Research Design}

The study used the causal-comparative or ex-post facto design. Kerlinger (1973) defines it as a systematic empirical enquiry in which the scientist does not have direct control of independent variable because their manifestations have already occurred or because they are inherently not manipulable. Inferences about relations among variables are made without direct intervention from concomitant variables of independent and dependent variables. Expost-facto research design so employed has permitted the examination of independent variable in retrospect for possible. That is family background as the independent variable is being studied after it has already exerted it influence on social adjustment of the students as the dependent variable. The independent variable is not maniupable by the researcher. Therefore, it has to be examined in order to determine its influence on present condition.

\section{Research Area}

The study area covered the Southern Senatorial District of Cross River State. It is made up of Akamkpa, Akpabuyo, Bakassi, Biase, Calabar Municipality, Calabar South and Odukpani Local Government Areas. This also form the Calabar Educational Zone of the Primary School Management Board; the area stretches from Biase Local Government Area in the South towards the Atlantic Ocean.

The area under study lies between latitudes $4^{0} 27^{\prime}$ and $5^{0} 32^{\prime}$, all South-East of equator. It is located within the tropical rain forest region of Nigeria. There are two distinct seasons, the wet and dry, with a 
short speel of harmattan between them. It also has well drained soil, which is fertile for cultivation of variety of crops. This area is bounded in the north by the central senatorial district of the state, in the south by Atlantic Ocean, in the east by the Republic of Cameroons and in the West by Akwa Ibom and Abia States (Ene, 2002 \& Kalu, 2008).

According to the 2006 provisional population census figures, the study area has an estimated population of about 26 million with a total density of 1.09 people per square likometer. Kalu (2008) \& Christian (2005) observed that the zone has four distinctive but interrelated traditional political systems administered by the Efiks, the Ejaghams and the Meo (Ukpat). The Major occupations of the people are farming, trading and fishing, though it is largely subsistent.

The zone houses the state capital of Calabar which is a tourist and industrial city (the Tinapa, Marina resort centres, cement factory, plywood, veneer industry, etc. (Ene, 2002 \& Christian, 2005 in Kalu, 2008). It is a purely civil service state for the area of employment.

There are sixty-four (64) public secondary schools in the zone and nine (9) out of the 64 are private schools, post secondary school management board's report (PPSMB).

\section{The Population of the Study}

The target population consisted of adolescents in junior secondary school in public institutions JSS 13 in South Senatorial District of Cross Rive State. the total number of adolescents students from the seven local government area according to figures given by the statistic unit of the state secondary schools management board (PPSMB) as at 2006 school year stood at 9378. This figure comprises 5133 males and 4245 females. JUA 64 government approved schools were in the study area as at the year 2006.

\section{The Sample}

The sample for the study consisted of 400 subjects. The subject included 200 males and 200 females. A breakdown of the composition of the sample by age shows that: 200 of the respondents were between ages 10-14 years, 200 respondents between 15 to 18 years.

Table1. Distribution of local government area; study population; number of selected schools and sex per local government area.

\begin{tabular}{|l|l|l|l|l|l|l|}
\hline S/n & $\begin{array}{l}\text { Local government areas } \\
\text { in southern sent. Of CRS } \\
\text { code }\end{array}$ & $\begin{array}{l}\text { Study } \\
\text { population }\end{array}$ & \multirow{2}{*}{$\begin{array}{l}\text { No of selected schools } \\
\text { per LGA }\end{array}$} & \multicolumn{2}{l|}{ No of students selected } & Total \\
\cline { 4 - 7 } & & & M & F & \\
\hline 1 & Akamkpa A & 1639 & 2 & 40 & 40 & 80 \\
\hline 2 & Akpabuyo B & 984 & 1 & 15 & 15 & 30 \\
\hline 3 & Bakassi C & 422 & 1 & 2 & 2 & 4 \\
\hline 4 & Biase D & 1437 & 1 & 50 & 50 & 100 \\
\hline 5 & Calabar Mun. E & 1482 & 2 & 40 & 40 & 80 \\
\hline 6 & Calabar South F & 2186 & 2 & 43 & 43 & 86 \\
\hline 7 & Odukpani G & 1228 & 1 & 10 & 10 & 20 \\
\hline & Total & 9378 & 10 & 200 & 200 & 400 \\
\hline
\end{tabular}

Source: field survey, 2017.

\section{The Sampling Technique}

The stratified random sampling technique was used to select the subjects for the study. The study area is made up of 7 local government areas with a total of 64 schools (Government owned and private schools) using hat and draw method of sampling, 10 schools were randomly sampled from the 64 schools within the south senatorial district. This was done by writing the names of all the schools in the areas, local government area per local government area in a different piece of paper. The piece of paper were squeezed and shuffled into a container. The researcher blindingly picked 10 pieces of paper which carried the names of the schools selected for the study.

Upon the selection of the 10 schools for the study, the subjects were randomly sampled from paper with yes or no printed on them were squeezed and shuffled for the students to pick. The picking points 
in each of the streams were separated for boys and girls to give balanced representation to both sexes in the sample. A total of 100 students each from the seven local government areas.

\section{Instrumentation}

A 28-item structured questionnaire was used for the collection of relevant and reliable data needed for this research. The items were generated according to the design of the research questions and hypotheses.

The questionnaire was divided into two parts. Part one consisted of the personal data of the respondents such as name of school, class, sex, age, family structure and family size whereas part two was made up of the items to which the respondents were required to respond to. A four-point scale of strongly agree (SA), agree (A), disagree (D), and strongly disagree (SD), was employed to obtain responses from the respondents.

\section{Validation of Instrument}

The 28 items in the questionnaire were drawn from the variables under study. The items were constructed to show the relationship of the variables and the hypotheses formulated. Each of the items on the questionnaire was well examined by the project supervisor and some experts in test and measurement to ascertain the face validation of the instrument. This was done to assure that the items measure what they purposed to measure. The items were certified valid, unambiguous and relevant to the study.

\section{Reliability of the Instrument}

In order to ascertain that the research instrument has internal consistency in measuring whatever it supposed to measure, the instrument was pilot-tested on 400 randomly sampled secondary students in Calabar South. The first administration of the instrument was followed by the second administration of the same instrument to the same students after an interval of two weeks. The data generated from the two administrations were subjected to correlation analysis using Pearson Product Moment Method.

The correlated scores yielded a reliability coefficient of 0.99 which indicates that the instrument was reliable.

\section{Data Collection Procedure}

The principal's permission was solicited and obtained. The questionnaire was administered personally by the researcher to the subjects in the sampled schools with the assistance of some teachers in these schools. The purpose of the investigation was briefly explained to them, while the items of the instruments as contained in the questionnaire were fully explained for proper understanding by subjects. 400 copies of questionnaire were administered to student individually, in all the secondary schools under study. Respondents were assured that whatever information they supplied on the questionnaire would in no way be used against them. They were also offered enough time to complete the instrument. 350 copies of the completed questionnaire were collected from students for scoring and analysis.

\section{Data Preparation and Scoring}

A key was developed in scoring the instrument for analysis on the basis of which all the information obtained from the respondents were coded. The items in the questionnaire were sorted out according to the variables they were designed to measure and appropriately coded. The following coding pattern was adopted in each of the questionnaire.

Table2. Coding schedule

\begin{tabular}{|l|l|l|l|l|}
\hline S/no & Variables & Main Score & Main Score & Column \\
\hline 001 & School & 1 & 10 & 1 \\
\hline 002 & Class & 1 & 10 & 2 \\
\hline 003 & Sex & 1 & 2 & 3 \\
\hline 004 & Age & 1 & 3 & 4 \\
\hline 005 & Family type & 1 & 5 & 5 \\
\hline
\end{tabular}


Influence of Family Background on Social Adjustment of Adolescent Students of Southern Senatorial District of Cross River State, Nigeria

\begin{tabular}{|l|l|l|l|l|}
\hline 006 & Family structure & 1 & 6 & 6 \\
\hline 007 & Family size & 1 & 5 & 7 \\
\hline 008 & Parental attitude & 1 & 2 & 9 \\
\hline 009 & Social adjustment & 11 & 25 & 10 \\
\hline
\end{tabular}

The key for scoring the instrument in part II A and B was as follows:

$\begin{array}{lll}\text { Strongly agree } & = & 4 \text { points } \\ \text { Agree } & = & 3 \text { points } \\ \text { Disagree } & = & 2 \text { points } \\ \text { Strongly disagree } & = & 1 \text { points }\end{array}$

Four (4) points indicated the most positive response while one point indicated the most negative response and the reverse for the negatively framed item. Each response was given a degree of scores, as indicated above, the scores on all the times were recorded and summed up for each respondent. The mean and standard deviation with other summary data were prepared for statistical analysis.

\section{Procedure for Data Analysis}

Data analysis was done hypotheses by hypotheses using independent t-test analysis at 0.05 level of significance.

Hypothesis 1: There is no significant relationship between adolescent students' family type and social adjustment.

Dependent Variable: Students social adjustment

Statistical Technique: independent t-test analysis.

Hypothesis 2: There is no significant relationship between adolescent students' family structure and social adjustment

Independent Variable: family structure (intact family and not intact family)

Dependent Variable: social adjustment

Statistical Technique: independent t-test analysis.

Hypothesis 3: There is no significant relationship between adolescent students' family size and social adjustment.

Independent Variable: family size (large and small family)

Dependent Variable: Students social adjustment

Statistical Technique: independent t-test analysis.

Hypothesis 4: There is no significant influence of parental attitude on students' social adjustment.

Independent Variable: parental attitude (positive and negative attitude)

Dependent Variable: Students social adjustment

Statistical Technique: independent t-test analysis.

\section{Method of Data Analysis}

Data analysis was done hypothesis by-hypothesis with appropriate statistical technique. All the hypotheses were tested at the 0.05 level of significance.

\section{DATA ANAlysis ReSUlts AND Discussion}

This is presented hypothesis-by-hypothesis analysis of the data obtained, it interpretation, discussion and summary of findings.

\section{Hypothesis Testing \\ Hypothesis One}

Family type does significantly influence students' social adjustment. Postulated in the null form, this hypothesis was tested using the independent $\mathrm{t}$-test analysis. The result is presented on the table below. 
Influence of Family Background on Social Adjustment of Adolescent Students of Southern Senatorial District of Cross River State, Nigeria

Table3. Independent t-test analysis of the influence of family type on students' social adjustment

\begin{tabular}{|l|l|l|l|c|}
\hline \multicolumn{1}{|c|}{ Variable } & \multicolumn{1}{|c|}{ N } & \multicolumn{1}{c|}{ SD } & t-cal \\
\hline Monogamous family & 250 & 48.35 & 8.48 & \multirow{2}{*}{7.82} \\
\hline Polygamous family & 100 & 41.52 & 6.89 & \\
\hline
\end{tabular}

$p>; 0.05, d f=348$, Crit, $t=1.96$

The analysed data in the above table reveals that the calculated t-value of 7.82 is greater than the table value of 1.96 when tested at 0.05 level of significance with 348 degrees of freedom. Since the calculated value is higher than the critical value the null hypothesis was rejected while the alternative hypothesis was accepted. This implies that there is a significant influence of family type on students' social adjustment.

\section{Hypothesis Two}

Family structure does not significantly influence students' social adjustment. Stated in the null form, this hypothesis was tested using the independent $\mathrm{t}$-test. The result is present in the table below.

Table4. Independent t-test analysis of the influence of family

\begin{tabular}{|l|l|l|l|c|}
\hline \multicolumn{1}{|c|}{ Variable } & \multicolumn{1}{c|}{ N } & XD & t-cal \\
\hline Intact family & 200 & 21.68 & 4.62 & \multirow{2}{*}{3.66} \\
\hline Not intact family & 150 & 19.32 & 4.43 & \\
\hline
\end{tabular}

$p>; 0.05, d f=348$, Crit,$t=1.96$

The analysis of the above table shows that the computed t-value of 3.66 is greater than the critical value of 1.96 when tested at 05 level of significance with 348 degrees of freedom. Consequently, the null hypothesis was nullified whereas the alternative hypothesis was retained. This means that family structure significantly influences students social adjustment.

\section{Hypothesis Three}

There is no significant influence of family size on students' social adjustment. Posited in the null form, this hypothesis was equally tested using the independent t-test. The result of the analysis is shown in the table below.

Table5. Independent t-test analysis of the influence of family size on students' social adjustment

\begin{tabular}{|l|l|l|l|c|}
\hline \multicolumn{1}{|c|}{ Variable } & \multicolumn{1}{c|}{$\mathbf{N}$} & \multicolumn{1}{c|}{ SD } & t-cal \\
\cline { 1 - 4 } Small family & 180 & 16.12 & 3.72 & 5.39 \\
\hline Large family & 170 & 13.83 & 3.83 & \\
\hline
\end{tabular}

$p>; 0.05, d f=348$, Crit,$t=1.96$

The analysis data in the above table indicates that the calculated t-value of 5.39 is greater than the table value of 1.96 when tested at .05 level of significance with 348 degrees of freedom. This result is also positive and therefore reject the null hypothesis whereas the alternative hypothesis was accepted. Implicit in this result is the fact that there is a significant influence of family size on students' social adjustment.

\section{Hypothesis Four}

There is no significant influence of parental attitude on students' social adjustment. This hypothesis which was stated in the null form was tested using the independent t-rest analysis. The result is presented in the table below.

Table6. Independent t-test analysis of the influence of parental attitude onstudents social adjustment

\begin{tabular}{|l|l|l|l|c|}
\hline \multicolumn{1}{|c|}{ Variable } & N & X & SD & t-cal \\
\hline Parents with positive attitude & 220 & 18.75 & 4.50 & \\
\hline Parents with negative attitude & 180 & 41.09 & 4.32 & 10.54 \\
\hline
\end{tabular}

$p>; 0.05, d f=348$, Crit, $t=1.96$

The analysis in the table above reveals that the computed t-value of 10.54 is greater than the critical value of 1.96 when tested at .05 level of significance with 348 degrees of freedom. Since the 
Influence of Family Background on Social Adjustment of Adolescent Students of Southern Senatorial District of Cross River State, Nigeria

calculated value is greater than the table value, the null hypothesis nullified whereas the alternative hypothesis was accepted.

This implies that parental attitude significantly influence sstudents' social adjustment.

\section{Discussion of Findings}

\section{Family Type and Student's Social Adjustment}

The finding on the first hypothesis disclose that student $\mathrm{s}$ who come from monogamous families experience a healthy interpersonal relationship due to the smallness of the family. Conversely, the findings further reveal that students from polygamous homes often exhibit anti-social behaviours such as quarreling, fighting, disassociation, from family members, disrespect due to disagreement which is prevalent among polygamous families.

From the foregoing, while the former could impact positively on the student's social adjustment, the later could undoubtedly impact negatively on student's social adjustment. In line with these findings, Obidi (2003), reported that regardless of age, Nigerian adolescents from monogamous families were generally supportive of traditional moral values such as respect and obedience to parents, elders, and societal norms. The only exception was those families whose beliefs run counter to the societal norms but generally the adolescents from monogamous families proved adjusted than students from polygamy families. In the same, Kalu (2008) opined that monogamy is a divine marriage institution meant for able and adjusted family and for the building of upright society. Christian (2005) and Kalu (2008) posited that polygamy and broken families have contributed to a greater extent to the antisocial activities of man and woman.

\section{Family Structure and Student's Social Adjustment}

The findings on the second hypothesis shows that students from families which are intact adjust easily because their parents are always around them to encourage them to cultivate and continually exhibit ethically acceptable social behaviours that are critical to their social adjustment within and outside the context of the home which could translate into their academic achievement. On the converse, the findings also indicate that delinquent behaviours such as physical abuse and verbal abuse which limit student's ability from adjusting socially are more prevalent among students from broken homes. This simply explains the variations on the academic achievement of students. In line with these findings, kalu (2008) found that students from intact families have higher peer intergeneration, high selfconcept, lower aggressive level and lower level of truancy than their counterparts from divorced and remarried families. Their study concluded that less conflict or stressful relationship, parental social adjustment, model adaptations are responsible for the student's social adjustment. Supportingly, Nweke (1989) posited that broken homes lead to a dysfunction of the system, confusion for the children malfunction socially, emotionally, morally and academically and that adolescents from broken family are fraught with retardation.

\section{Family Size and Student's Social Adjustment}

The results on the third hypothesis indicates that family size tremendously influence student social adjustment. However, the impacts of family size differ depending on the smallness or largeness of the family. For students from small families, the results show, that students from small families with high socio-economic status, experience little or no difficulty in adjusting socially since their parents are themselves literates and have their financial capacity to create and also subject their children/wards to learning-stimulating social environment that could contribute a great deal to their social development. The findings reveal on the contrary that students from relatively large families face the challenge of social adjustment both within and outside the home because of frequent petty wrangles, disagreement over equal educational opportunities, allocation of family resources all of which can be attributed to large family size, low social status and low economic muscles. This findingare in line withDonatus. \& Bankole (2013)whose studies reveals that family size is significantly correlated with nearly all the dependent variables; the only exceptions are material inconsistency of discipline and expectation. Generally, their data revealed an inverse relationship between family size and the degree of perceived parental support. Paramanik, Saha, \& Mondal, (2014) added that in large families, there tend to be defective parents - child relationship which could result to unsuccessful performance at school due to anti-social activities. 


\section{Parental Attitude and Student's Social Adjustment}

The result of the four hypotheses indicates that the ease and the rate at which children adjust socially is largely dependent on the attitude of their parents towards the social upbringing of their children. The results show that parents who are democratic positive in their attitude to the social life of their siblings tend to elicit goal-directed behaviours through influence and also encourage the participation of their children in family decision thus engender in them a higher sense of commitment to domestic and external social responsibilities.

On parents with negative autocratic attitude, the findings indicate children under such parents are often commanded, threatened, intimidated, scolded and are never allowed the opportunity to make any input during family meetings. Consequently, such parents instill in their children a sense of inferiority of complex, and negative emotions since the home atmosphere is charged with fear and unhealthy parent/child relationship. Undoubtedly, this could translate to limiting factors to the child's social adjustment as well as his academic performance.

On parents with laissez-faire attitude, the findings of this study show that parent who are carefree encourage their children to develop poor social attitude that leads to truancy, cultism, stealing, examination malpractice, verbal abuse, etc which affect their social development.

In line with these results, Kalu (2008) in his study of the influence of parental attitude on self-concept and social adjustment with sample 720 adolescent, (300 boys and 430 girls) discovered that adolescent from positive or democratically oriented families are better socialized. They are thus more cooperative, friendly, loyal, cheerful and socially adjusted. Hurlock (2002) postulated that negative or authoritarian leadership style is that style which is adopted by parents on their adolescents that involves restricting their autonomy, value, presentation of order and traditional structure inhibiting verbal 'give and take' and encouraging parents word as what is right.

\section{SUMMARY, CONCLUSION AND RECOMMENDATION}

This summarizes the preceding study, draws conclusion, advance recommendations and suggestions for further studies.

\section{SUMMARY}

The objective of research was to investigate the influence of family background on social adjustment of adolescents in southern senatorial district of Cross River State. Four research questions and hypotheses were formulated to guide this study.

The views and research findings of other scholars in areas that related to the topic under study were reviewed. This study adopted the causal comparative research design and the population comprised of 9,378 junior secondary school students out of which 400 subjects were randomly selected from 10 schools in the area under study to form the sample. A structured questionnaire comprising of 28 items was developed, validated and tested for reliability using test re-test method. They data obtained was tested using the independent t-test analysis. The analyzed data culminated in the following findings:

There is a significant influence of family type on student's social adjustment. Family structure tremendously influence student's social adjustment. There is a significant influence of family size on student's social adjustment parental attitude significantly influence student's social adjustment.

\section{CONCLUSION}

It is evident from the findings of this investigation that family type, family structure, parental family size, democratic, autocratic and laissez-faire parenting style attitude greatly influence student's social adjustment. This is because the family forms the foundation for the child first social environment. The child's education starts from the home and spills over to other institutions such as the school. The family therefore influences the child's education to a large extent.

In Nigeria, the family still remains the dominant and significant group into which the child is biologically, psychological and socially attached. Some families are richer and bigger than others, while some are educationally enlightened than other. Since children spend a greater part greater part of life in the family, the family therefore have a profound impact on their lives. 
Influence of Family Background on Social Adjustment of Adolescent Students of Southern Senatorial District of Cross River State, Nigeria

\section{RECOMMENDATION}

Sequel to the findings of this research, some recommendations were made:

1. The government should establish more industries and create enabling environment to encourage investment by the private sector as it is hoped that such public/private school partnership will create more employment opportunities that will empower people economically.

2. The government should encourage family planning in order to reduce number of children per parents to at least four

3. The parents should adopt democratic parenting (style) attitude in the management of their families since this style is result oriented relative to the autocratic and laissez-faire style as evidenced in the findings of this research.

4. The parents, guidance counselors the school and the church should intensify efforts at the propagation and re-orientation of societal values.

\section{REFERENCES}

[1] Adedibu, O. (1986). Relationship between family background and Nigerian adolescents attitude to more norms in realities to and challenges of Nigeria education system, Education Studies Association of Nigeria, 11, 24-26.

[2] Adler, A, \&Ryckman, R. M. (1985). Understanding human nature. New York: Greenberg.

[3] Akang, E. U. (1982). The effect of family times on adolescent adjustment. Unpublished M.Ed Thesis, University of Ibadan.

[4] Akpan, E. (1998). Facility utilization and its impact on the achievement of SS II students of Business Education in Calabar Urban, Unpublished M.A Thesis, University of Calabar, Calabar.

[5] Akpochafo, W. (1987). Study guide on the sociology of education (ModelQuestionsandAnswers). Warri: Erusam.

[6] Amato, P. R. (1987). Family process in one-parent, step parent and intact families: the child's point of view. Journal of Marriage and the Family. 49, 327-337.

[7] Ansbacher, H. L. \&Ansbacher, R. R. (Eds.) (1973). Superiority and social interest: A collection of later writings. New York: Viking.

[8] Attoe, E. O. (1999). Social responsibility and science achievement among secondary school students in Cross River State. Unpublished M.A Thesis, University of Calabar, Calabar.

[9] Ayeni, O. (1983). The influence of three ecological variables on the psychological development of Nigerian children. Nigerian Journal of Education Psychology 1, 119-128.

[10] Bakare, C. G. (1981). Some psychological correlates of academic success and failure. African Journal of Educational Research, 2, 11-12.

[11] Bandura, A. \& Walters, R. (1959). Adolescent aggression a study of influence of the children rearing practices and family interrelationship, New York.

[12] Bandura, A. \& Walters, R. H. (1983). Adolescent aggression. New York: Ronald.

[13] Bandura, A. (1971). Social learning theory. New York: General Learning Press Greenberg.

[14] Bandura, A. (1977). Peer, family and personality domains as related to adolescents during drug behaviour. Psychological Reports, 42, 1023-1103.

[15] Baumrind, D. (1966). Effects of authoritative parental control on child behavior and child development. Journal of Marriage and Family Living 29, 336-376.

[16] Baumrind, D. (1967). Child care practices on teaching three patterns of pre-school behaviour. Genetic Psychology Monograph, 75, 315-388.

[17] Baumrind, D. (1980). New direction in socialization research. American psychology, 36, 639-659.

[18] Baumrind, D. (1984). Being competent children in W. Damon (Ed.) Child development today and tomorrow. 7 (124-130) San Francisco: Jossy-Bass.

[19] Baurind, D. (1971). Current patterns of parental authority Developmental Psychology Monograph, 4, 246267.

[20] Bell, W. \& Vogel, E. (1986). A modern introduction to the family gleconas. Liinis: Free Press.

[21] Boocook, S. S. (1972). An introduction to the sociology of learning. Houghton: Miffin.

[22] Bull, N. J. (1973). Moral education. London: Redwood. 
Influence of Family Background on Social Adjustment of Adolescent Students of Southern Senatorial District of Cross River State, Nigeria

[23] Burchinal, L. G. (1964). Characteristics of adolescent from unbroken broken and reconstituted family. Journal of Marriage and Family, 26, 44-51.

[24] Chandler, M. J. (1982). Social knowledge and social structure. In F. C. Serafica (Ed.). Social cognition and social relations in context, 9, 78-81. New York: Cruiford.

[25] Christian, E. (2005). Availability and utilization of instructional material and students' attitude towards Christian religions studies in Calabar Metropolis. Unpublished PGDE Project: University of Calabar, Calabar.

[26] Coleman, J. C. (1972). Abnormal psychology and modern life. India. Taraorenal Son.

[27] Cooly, C. H. (1902). Human nature and social order. New York: Seribens Press.

[28] Crosser, S. (1997). Helping young children to develop character. Opinion paper. University of Wisconsin Stout.

[29] Day, P. (1981). An opinion survey of the students in the University of Ife. Journal of Economic and Social Studies, 7, (3), 5-10.

[30] Denga, D. (2006). Educational and social psychology for schools and other social organization. Calabar: Rapid Educational Publishers.

[31] Denga, D. I. (1981). Juvenile delinquency among polygamous families in Nigeria. Journal of Social Psychology, 114, 3-7

[32] Denga, D. I. (1983). The school counselor in developing nation: problem and prospects. Jos: Savannah Press.

[33] Denga, D. I. (1988). Educational and social psychology for schools and other social organization. Calabar: Rapid Educational Publishers.

[34] Donatus, o. O. \& Bankole, m. O. (2013) family type and attitude to sexual promiscuity of adolescent students in Ekiti state, Nigeria. European Scientific Journal. Vol.9, No.17 ISSN: 1857 - 7881 (Print) e ISSN 1857- 7431.

[35] Effiong, M. E. (1982). Juvenile as a function of family disorganization: a case study of inmates of Calabar remade home. An unpublished M.A Thesis, University of Calabar, Calabar.

[36] Effiong, U. O. (2005). Family rearing styles and self, other perception among secondary school students in Oron, Akwa Ibom State. An unpublished M.A Thesis, University of Calabar, Calabar.

[37] Egu, D. C. (1988). Family influence on self concept and social adjustment of adolescents in Imo State. An unpublished Ph.D. Dissertation, University of Calabar, Calabar.

[38] Ekara, J. N. (2001). Relationship between home background and academic performance of students in government. An unpublished PGDE Project: University of Calabar, Calabar.

[39] Elder, G. (1963). Parents power legitimization and its effect on the adolescents. Sociology, 3, 15-20.

[40] Elder, G. (1965). Childhood and society. New York: www.norton.

[41] Ene, E. I. (2002). Family socialization patterns and occupational preference of adolescents senior secondary three students in South Senatorial District of Cross River State. An unpublished M.Ed Thesis, University of Calabar, Calabar.

[42] Erikson, E. H. (1963). Childhood and society. New York: Norton.

[43] Ette, A. A. (1997). Influence of parental closeness on peer inclination and social adjustment among secondary school learners in Akwa Ibom State. M.Ed. Research project: University of Calabar, Calabar.

[44] Ette, A. A. (2002). Influence of child rearing practices on adolescents students social adjustment in Uyo Local Government Area. among secondary school learners in Akwa Ibom State. M.Ed. Research project: University of Calabar, Calabar.

[45] Eyo, M. B. (2002). Family background, moral values and discipline behavior of secondary school students in Cross River State. An unpublished Ph.D. Dissertation. University of Calabar, Calabar.

[46] Eze, E. E. (1985). Family types and psychological adjustment of students in Calabar Municipality.An $u$ npublished M.A Thesis, University of Calabar, Calabar.

[47] Federal Republic of Nigeria (1981). National Policy on Education (3 ${ }^{\text {rd }}$ ed.) Lagos: Federal Government Press.

[48] Flanks, R. (1976). The liberated generation. An emploration of the roots of students' protest. Journal of Education in Development Area, 11, (23), 20-23.

[49] Fletcher, A. C., Darling, N. E., Steinberg, L., \&Dornbush, S. M. (1995). The company to keep: relation of adolescents' adjustment and behaviour to their friends' perceptions of authoritative parenting in the social network. Development Psychology, 31, (2) 300-310. 
Influence of Family Background on Social Adjustment of Adolescent Students of Southern Senatorial District of Cross River State, Nigeria

[50] Fontama, D. (1981). Psychology for teachers. London: MC Millan Press.

[51] Freud, S. (1933). New introduction lecturers on psychoanalysis. New York: Norton.

[52] Freud, S. (1960). A general introduction to psychoanalysis. New York: Washington Square Press.

[53] Fromm, B. (1939). Selfishness and self love. Psychiatry, 2, 507-523.

[54] Good, C. Y. (1973). Dictionary of education. New York: MC Graw-Hill.

[55] Goode, W. J. (1964). The family, children and family desolation. Englewood Cliffs, New Jersey: Prentice Hall.

[56] Hakes, S. (1977). Parental socio-economic status academic achievement and career aspiration of adolescent. Journal of social psychology, 62 (4) 161.

[57] Hall, G. S. (1905). Adolescence. Its psychology and its relations to physiology, anthropology, sociology, sex, crime, religion, and education. (Vol. 1). Englewood Cliffs. N. J: Prentice-Hall.

[58] Harvighurst, R. T. \& Peak, A. C. (1974). Adolescent character and personality. New York: John Wiley.

[59] Herzog, E. \&Suda, C. (1971). Boys in fatherless families department of health education and welfare office of child development. United State: Washington DC.

[60] Hoffman, M. (1970). Moral development. In P. A. Mussen (Ed.). carrnichee annual of child psychology, 11, 149-155, New York: Wiley.

[61] Holy Bible (1979). New King James Version. Expended Education: Thomas Nelson Publishers.

[62] Hower, J. T. \& Edwards, K. (1979). The relationship between moral character and adolescents' perception on parental behaviour. Journal of General Psychology, 135, 23-32.

[63] Hower, J. T. (1980). Parent behaviour and moral education. In D. B. Cochrance\& M. Manley (Eds.). Reasoning: practical approaches. New York: Praeger.

[64] Hurlock, E. B. (1972). Child development. New York: Mc Graw-Hill.

[65] Iheanacho, R. A. E. (2002). Psychology of learning. Owerri: G.O.C. International Publishers.

[66] Imaobong, A. D. (2002). Parenting styles and social adjustment of adolescent student in Akwa Ibom State. Unpublished Ph.D. Dissertation. University of Calabar, Calabar.

[67] James, W. (1950). The principles of psychology. New York: Dover.

[68] Jersile, E. (1978). The psychology of adolescence ( $3^{\text {rd }}$ ed.): Macmillan.

[69] Kegan, J. \& Freeman, M. (1963). Relation of childhood intelligence, maternal behaviour, and social class to behaviour during adolescence. Child Development, 34, 899-471.

[70] Klein, H. (1988). Adolescence, youth, and younghood. Youth and society, 21, (4), 446-471.

[71] Leslie, G. R. (1979). The family in social context. New York: Oxford University Press.

[72] Lindgren, H. C. (1976). Educational psychology in the classroom ( $5^{\text {th }}$ ed.). New York: John Wiley \& Sons.

[73] Lipset, O. P. \&Boudix, L. N. (1968). Home and child education. Sociology of education, New York: Wiley.

[74] Maduakonam, A. E. (1986). A survey of causes of moral decadence among youths in Enugu urban: Implication of Guidance and counseling. The Counsellor, 6 (2), 132.

[75] Mawah, A. N. (1989). The influence of home background on disciplinary problems among senior secondary school students. An unpublished Research Project. University of Port Harcourt.

[76] Mbiti, J. S. (1973). Introduction to African religion. Kent: Whistablelith, Whitstable.

[77] Mbiti, J. S. (1981). Love and marriage in Africa. London: Macmillan.

[78] Mead, M. (1970). The family. New York: Collier, Macmillan.

[79] Mead, S. H. (1934). Mind, self and society. Chicago: University of Chicago Press.

[80] Medinnus, G. R. \& Johnson, R. C. (1976). Child and adolescent psychology. Canada: John Wiley and Sons.

[81] Moorish, I. (1972). The sociology of education. An introduction. London: George Allen and Unwin.

[82] Murdock, D. (1949). Social structure. Glencose: Macmillan.

[83] Nnena, M. N. \&Nweke, C. C. (1989). Marital instability in Nigerian homes: Possible guidance. Enugu, Totan.

[84] Obidi, S. S. (1993). A study of the reaction of secondary grammar school students to indigenous moral values in Nigeria. Journal of Negro-Education, 62 (1), 82-90.

[85] Odunze, D. (1982). How to prepare for marriage. The family circle. Enugu: Donze Press. 
[86] Okon, C. E. (1994). Family influence on self-concept and social adjustment of adolescents in post primary schools in Calabar Municipality. M.Ed. Research Project Department of Education Foundation, Guidance and Counselling. University of Calabar.

[87] Oloruntimehim, O. (1984). Opportunity and crime. An explanation of white collar criminality in Nigeria. A seminar paper presented to the Department of Sociology and Anthropology. University of Iie-Ife: Nigeria.

[88] Onyejiaku, F. O. (1986). Value orientation: A remedy for juvenile delinquency. The Counsellor, 6, 2-8

[89] Onyejiaku, F. O. (1991). Psychology of adolescence, Calabar: Rapid Publishers.

[90] Ozoemen, T. O. (2002). Childhood experience in a broken home and social adjustment of secondary school students in Calabar Municipality. An unpublished M.Ed. University of Calabar, Calabar.

[91] Paramanik, J.; Saha, B. \& Mondal, B. C. (2014). Adjustment of Secondary School Student with Respect to Gender and Residence. American Journal of Education Research 2(12) pp 1138-1143. DOI: 10.12691/education-2-12-2.

[92] Parson, T. \& Bales, R. F. (1995). Family socialization and interaction process, New York: Free Press.

[93] Power, S. I. (1988). Moral judgement development within the family. Journal of Moral Education, 17, 209-219.

[94] Raschke, H. \&Raschke, V. (1979). Family conflict and children self-concept: A comparison of intact and single parent families. Journal of Marriage and Family, 16, 367-374.

[95] Robinson, P. (1980). Parents of beyond control behaviour. An inventory. Child Development, 36, $413-424$.

[96] Rubin, R. (1963). Maternal touch. Nursing outlook, 11, 828-831.

[97] Russell, I. L. (1976). Behaviour problems of children form broken and intact homes. Journal of Educational Sociology, 31, 124-129.

[98] Rutter, M. (1971). Parent-child separation: Psychological effects on children. Journal of child psychology and psychiatrics deiEnfnt., 17(2), 479-514.

[99] Rychman, R. M. \& Sherman, m. M. (1974). Theories of personality. New York: D. Van Monstrand.

[100]Rychman, R. M. (1985). Personality.Calenvirw, ill: Scott Foresman.

[101]Saltztein, H. D. \&Hopman, P. C. (1987). Social influence and moral development; A prespective on the role of parents and peers. In T. Linkona (Ed.) moral development and behaviour: The research and social issues, 8, 45-55, New York: Rinehart and Winston.

[102]Schamberg, L. B. \& Smith, K. U. (1982). Human development. New York: Macmillan.

[103] Schwech, D. \& Emerick, R. (1976). The young male adolescent perception of early child of socioeconomic status and family size. Sociometry, 35, (2)

[104]Simon, S. B. \&Wirschenbaum, A. (1978). Values classification: A handbook of practical strategies for teachers and students. New York: Dood MEAD.

[105]Skinner, B. F. (1953). Science and human behaviour. New York: Macmillan.

[106]Smith, B. O. (1982). Discipline. London: Collier, Macmillan

[107]Smith, N. M. (1967). Family relationship communication and concept. Journal of Marriage and Family living. 12, 30-42.

[108] Sorokin, P. (1980). Divorce statistics. New York: McGraw-Hill.

[109]Steinberg, L. (1987). Single parents, step parents and the susceptility of adolescents to antisocial peer pressure. Journal of child development, 58, 269-275.

[110]Uba, A. (1983). Teacher as para-counsellors in the 6-3-3-4 system of education counselor. Journal of the Counselling Association of Nigeria, 5, 3-4.

[111]Udo, T. (1982). Parental educational background and adolescents discipline behaviour. Unpublished B.A. Education project. University of Lagos.

[112]Udom, P. (1982). Crisis in Nigerian schools. Ibadan: Adelakum Press.

[113]Ufot, O. A. (1980). Students' protests, riots and demonstrations. The Calabar Educators, 2, 8-23.

[114]Uwe, E. A. (2005). Theories of counseling and psychotherapy. Lagos: El Sapphire Press.

[115]Vogel, E. A. (1962). The democratization of family relationship in Japanese urban society in unmarried mothers. New York: The Free Press of Glence.

[116]Yoloye, E. A. (1972). Socio-economic background and school population: A survey of the background of children in three types of schools. In M. O. A. Durojaiye (Ed). Psychological guidance of the school child, 12, 16-34, London: Evans brothers. 


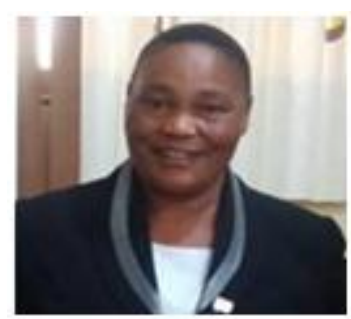

Dr Paulina, is an erudite scholar who holds a Doctorate degree in Medical Surgical Nursing. Having worked as a registered nurse, and a community primary healthcare tutor for over 25 years, at the University of Calabar Teaching hospital, Paulina is currently a lecturer at the Department of Nursing Sciences, University of Calabar, Nigeria.

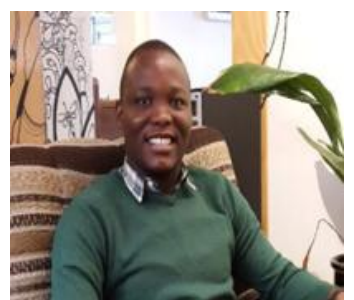

Ackley, is a social innovation campaigner who have designed and supervised many building designs ranging from residential to commercial buildings, and a guru in many design and building performance analysis software's. I am a scholar and researcher who is keen to add value to lives through innovative, creative and sustainable solutions. I have been involved in many crossdisciplinary projects from conceptualization to finishing.

Citation: Paulina Akpan-Idiok, Aniebietabasi Ackley. "Influence of Family Background on Social Adjustment of Adolescent Students of Southern Senatorial District of Cross River State, Nigeria" International Journal of Humanities Social Sciences and Education (IJHSSE), vol 5, no. 8, 2018, pp. 227-243 doi: http://dx.doi.org/ 10.20431/2349-0381.0508020.

Copyright: (c) 2018 Authors. This is an open-access article distributed under the terms of the Creative Commons Attribution License, which permits unrestricted use, distribution, and reproduction in any medium, provided the original author and source are credited. 